Practical Rails Social Networking Sites

Alan Bradburne 


\section{Practical Rails Social Networking Sites}

\section{Copyright $\odot 2007$ by Alan Bradburne}

All rights reserved. No part of this work may be reproduced or transmitted in any form or by any means, electronic or mechanical, including photocopying, recording, or by any information storage or retrieval system, without the prior written permission of the copyright owner and the publisher.

ISBN-13 (pbk): 978-1-59059-841-2

ISBN-10 (pbk): 1-59059-841-5

Printed and bound in the United States of America 987654321

Trademarked names may appear in this book. Rather than use a trademark symbol with every occurrence of a trademarked name, we use the names only in an editorial fashion and to the benefit of the trademark owner, with no intention of infringement of the trademark.

Lead Editors: Matthew Moodie, Chris Mills

Technical Reviewer: Paul Bentley

Editorial Board: Steve Anglin, Ewan Buckingham, Gary Cornell, Jonathan Gennick, Jason Gilmore, Jonathan Hassell, Chris Mills, Matthew Moodie, Jeffrey Pepper, Ben Renow-Clarke, Dominic Shakeshaft, Matt Wade, Tom Welsh

Project Manager: Kylie Johnston

Copy Edit Manager: Nicole Flores

Copy Editor: Heather Lang

Assistant Production Director: Kari Brooks-Copony

Production Editor: Kelly Winquist

Compositor: Susan Glinert

Proofreader: Elizabeth Berry

Indexer: Becky Hornyak

Artist: April Milne

Cover Designer: Kurt Krames

Manufacturing Director: Tom Debolski

Distributed to the book trade worldwide by Springer-Verlag New York, Inc., 233 Spring Street, 6th Floor, New York, NY 10013. Phone 1-800-SPRINGER, fax 201-348-4505, e-mail orders-ny@springer-sbm.com, or visit http://www.springeronline.com.

For information on translations, please contact Apress directly at 2855 Telegraph Avenue, Suite 600, Berkeley, CA 94705. Phone 510-549-5930, fax 510-549-5939, e-mail info@apress.com, or visit http:// WWW. apress. com.

The information in this book is distributed on an "as is" basis, without warranty. Although every precaution has been taken in the preparation of this work, neither the author(s) nor Apress shall have any liability to any person or entity with respect to any loss or damage caused or alleged to be caused directly or indirectly by the information contained in this work.

The source code for this book is available to readers at http://www. apress.com in the Source Code/Download section. 
For Mayumi 


\section{Contents at a Glance}

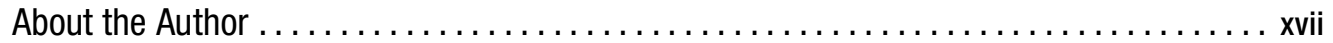

About the Technical Reviewer .....................................

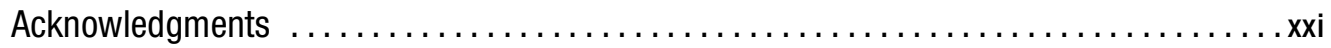

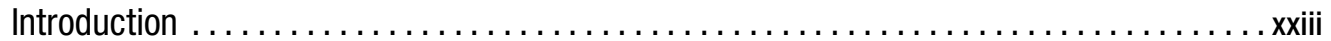

CHAPTER 1 Ruby, Ruby on Rails, and the RailsCoders Project $\ldots \ldots \ldots \ldots \ldots 1$

CHAPTER 2 Developing a Content Management System ............... 21

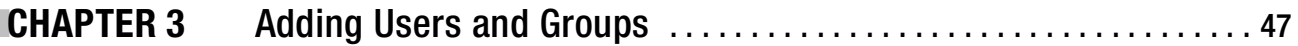

CHAPTER 4 Building a News Blog with RSS Feeds and an API ...........83

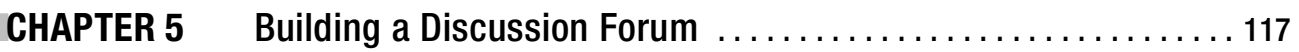

CHAPTER 6 Building a Blogging Engine with Web Services Support . . . . 153



CHAPTER 8 Sending E-mail and Building a Newsletter Mailing List ....... 217

CHAPTER 9 Adding Friends with XFN Details ..................... 247

CHAPTER 10 Adding Tags to the Photo Gallery .................... 277

CHAPTER 11 Creating Mashups and Integrating with Web $2.0 \ldots \ldots \ldots \ldots . \ldots 1$

CHAPTER 12 Adding User-Created Themes to the Blogging Engine . . . . . 329

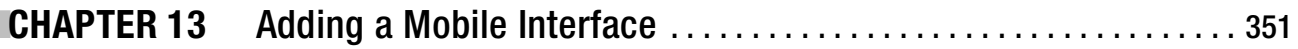

CHAPTER 14 Deploying, Optimizing, and Scaling the Application .......... 379






\section{Contents}

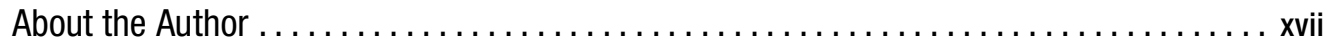

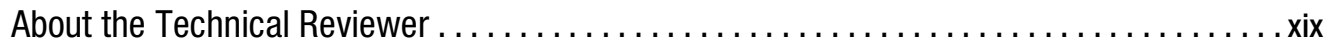

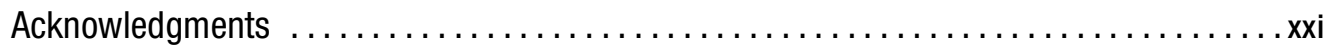



CHAPTER 1 Ruby, Ruby on Rails, and the RailsCoders Project ....... 1





A Brief History of Ruby ............................ 3

What Is Ruby on Rails? ......................... 4

Software Required to Build RailsCoders .................... 7

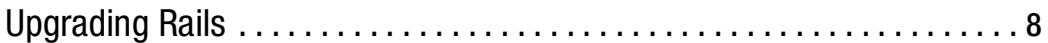

Installing Ruby, Rails, and MySQL $\ldots \ldots \ldots \ldots \ldots \ldots \ldots \ldots \ldots$

Installing on Windows $\ldots \ldots \ldots \ldots \ldots \ldots \ldots \ldots \ldots \ldots \ldots$





Creating the Skeleton of the Rails Application $\ldots \ldots \ldots \ldots \ldots \ldots \ldots 14$

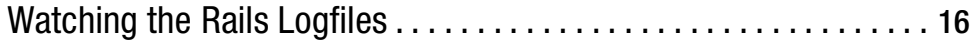

Setting up the Database ............................. 17

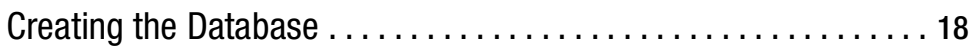

Configuring Rails to Use the Database $\ldots \ldots \ldots \ldots \ldots \ldots \ldots 18$

Testing the Database ............................ 19

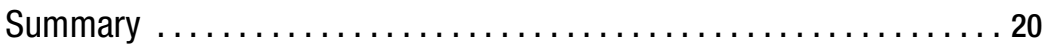

CHAPTER 2 Developing a Content Management System $\ldots \ldots \ldots \ldots 21$

Specifying the Feature Requirements $\ldots \ldots \ldots \ldots \ldots \ldots \ldots \ldots \ldots \ldots \ldots \ldots \ldots \ldots$

Rails, Routing, and REST ........................... 21

Traditional Rails Routes ........................... 22

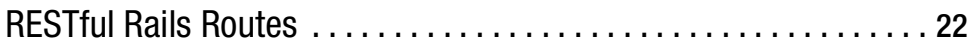

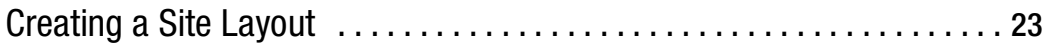

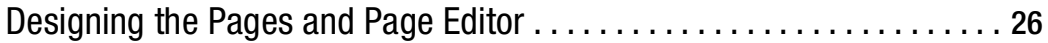

The Page Model .............................. 26

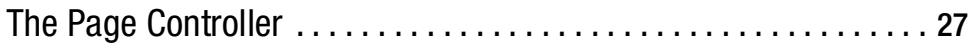


Creating the Page Model $\ldots \ldots \ldots \ldots \ldots \ldots \ldots \ldots \ldots \ldots \ldots \ldots \ldots 28$

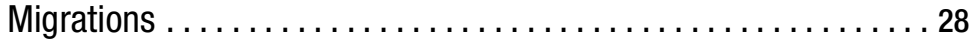

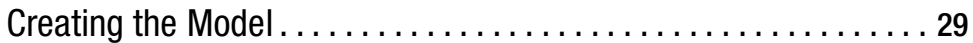

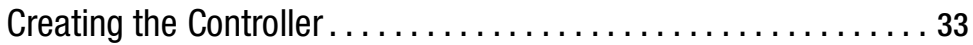

Setting Up a Default Page $\ldots \ldots \ldots \ldots \ldots \ldots \ldots \ldots \ldots \ldots . \ldots 1$

Adding a Link from the Sidebar Menu .................. 41

Testing ........................................ 42

Creating the Testing Database $\ldots \ldots \ldots \ldots \ldots \ldots \ldots \ldots, 42$

Developing Unit Tests for the Page Model................ 42

Extending the Content Management System $\ldots \ldots \ldots \ldots \ldots \ldots . \ldots 4$

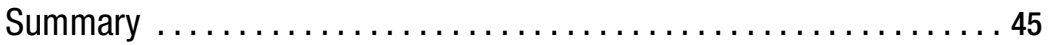

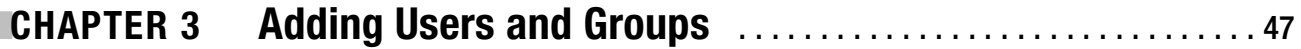

Specifying the Feature Requirements $\ldots \ldots \ldots \ldots \ldots \ldots \ldots \ldots 47$

Defining the User Model. ........................... 47

The Role Model and Join Table..................... 48

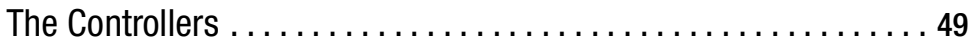

Sessions and Cookies ............................. 50

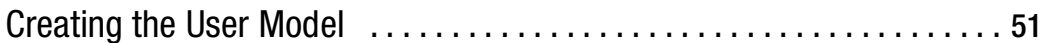

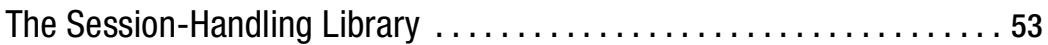

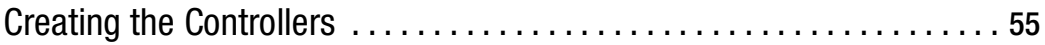

The Users Controller............................... 55

The Account Controller............................ 57

Creating the User Account Views $\ldots \ldots \ldots \ldots \ldots \ldots \ldots \ldots \ldots$

The New User View $\ldots \ldots \ldots \ldots \ldots \ldots \ldots \ldots \ldots \ldots \ldots \ldots$

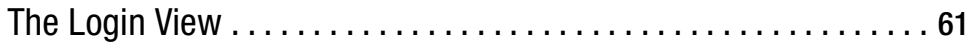

The Show User View. ............................. 62

Adding Administration Views $\ldots \ldots \ldots \ldots \ldots \ldots \ldots \ldots \ldots, \ldots \ldots \ldots$

Listing All Users in the Index View ....................6 64

Editing a User with edit.rhtml $\ldots \ldots \ldots \ldots \ldots \ldots \ldots \ldots \ldots 66$

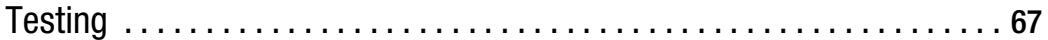

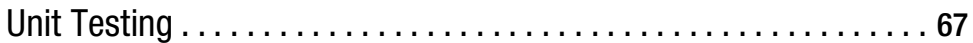

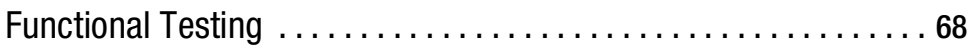

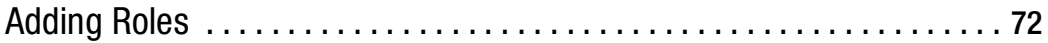

Creating the Role Model and Join Table $\ldots \ldots \ldots \ldots \ldots \ldots \ldots 72$

Checking a User's Roles . ......................... 74



Testing the Roles Functionality $\ldots \ldots \ldots \ldots \ldots \ldots \ldots \ldots \ldots \ldots \ldots$

Extending the User Management System $\ldots \ldots \ldots \ldots \ldots \ldots \ldots . \ldots 1$

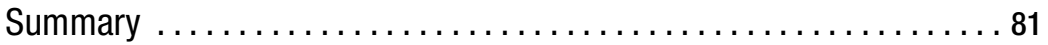


Specifying the Feature Requirements $\ldots \ldots \ldots \ldots \ldots \ldots \ldots \ldots, \ldots \ldots$

Textile Markup $\ldots \ldots \ldots \ldots \ldots \ldots \ldots \ldots \ldots \ldots \ldots \ldots \ldots . \ldots \ldots$

The Article Model $\ldots \ldots \ldots \ldots \ldots \ldots \ldots \ldots \ldots \ldots \ldots \ldots \ldots \ldots$

Defining the Category Model. $\ldots \ldots \ldots \ldots \ldots \ldots \ldots \ldots \ldots$

The Editor Role $\ldots \ldots \ldots \ldots \ldots \ldots \ldots \ldots \ldots \ldots \ldots \ldots \ldots \ldots$

The Articles Controller .......................... 86

The Categories Controller $\ldots \ldots \ldots \ldots \ldots \ldots \ldots \ldots \ldots \ldots$

Installing the RedCloth Gem $\ldots \ldots \ldots \ldots \ldots \ldots \ldots \ldots \ldots \ldots$

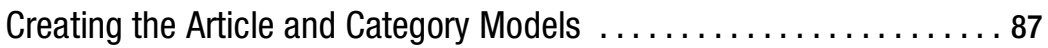

Writing the Database Migrations. ..................... 87

Defining the Relationships Among Models . . . . . . . . . . . 88

Defining the Validations .......................... 89

Automatically Nullifying category_id on Deletion . . . . . . . . . 89

Automatically Updating the published_at Field . . . . . . . . . . 89

Adding the Editor Role .......................... 90

Creating the Articles Controller and Views . . . . . . . . . . . . . . 91

Mapping the REST Resources ....................... 91

The Articles Controller ......................... 92

The Article Views . . . . . . . . . . . . . . . . . . . . . . . 98

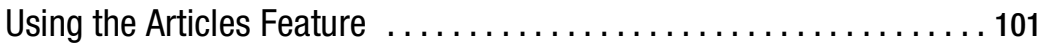

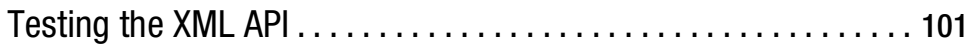

Adding HTTP Authentication for the API . . . . . . . . . . . 103

Testing the API Authentication ....................... 104

Creating the Categories' Controller and Views ............... 105

The Categories Controller ......................... 105

The Category Views .............................. 108

Adding a Link from the Sidebar Menu . . . . . . . . . . . . . 109

Manually Testing the News Blog System . . . . . . . . . . . . . 110

Testing the News Blog .............................. 110

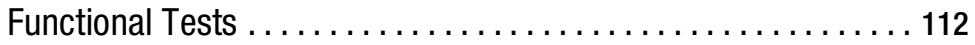

Integration Tests.............................. 114

Further Development of the News System $\ldots \ldots \ldots \ldots \ldots \ldots \ldots \ldots \ldots$

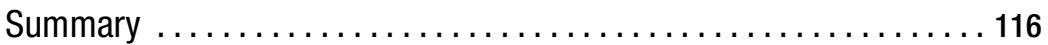


CHAPTER 5 Building a Discussion Forum $\ldots \ldots \ldots \ldots \ldots \ldots \ldots \ldots \ldots \ldots$

Specifying the Discussion Forum Requirements ............. 117

Defining the Forum Model $\ldots \ldots \ldots \ldots \ldots \ldots \ldots \ldots \ldots \ldots \ldots$

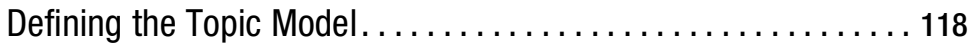

Defining the Post Model.......................... 119

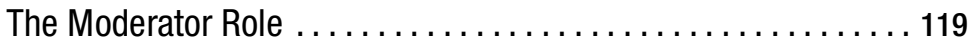

The Forum, Topic, and Post Controllers............... 119

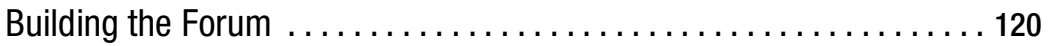

Building the Forum, Topic, and Post Models............. 120

Checking a User's Roles for Moderator Rights . . ........... 126

Adding the Nested Resource Route Mappings ............. 126

Modifying the Layout Template and Style Sheet........... 126

The Forums Controller and Views.................... 127

The Topics Controller and Views..................... 131

The Posts Controller and Views. ..................... 136

Adding a Link to the Sidebar Menu $\ldots \ldots \ldots \ldots \ldots \ldots \ldots \ldots 141$

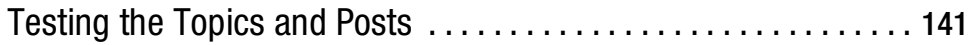

Restricting Actions to Moderators. . . . . . . . . . . . . . . 142

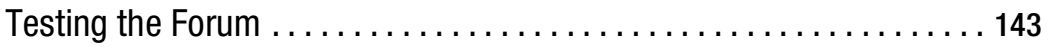

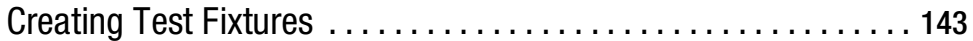

Creating the Functional Tests ........................ 144

Further Development of the Discussion Forum . . . . . . . . . . 150

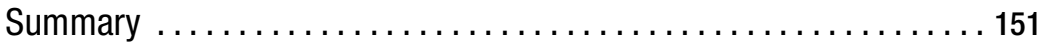

\section{CHAPTER 6 Building a Blogging Engine} with Web Services Support ..................... 153

Specifying the Blog Engine Requirements $\ldots \ldots \ldots \ldots \ldots \ldots \ldots \ldots \ldots \ldots$

The Entry Model . . . . . . . . . . . . . . . . . . . . . . 153

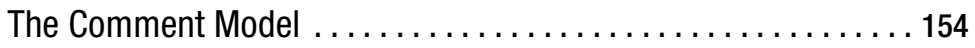

The User Model. ............................... 154



The Comments Controller ........................ 155

The Blogs Controller............................ 155

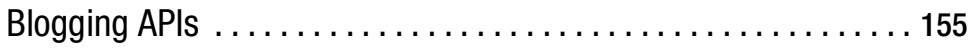

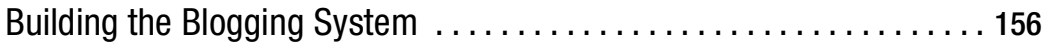

Generating the Blogging Scaffolding Code $\ldots \ldots \ldots \ldots \ldots \ldots 156$

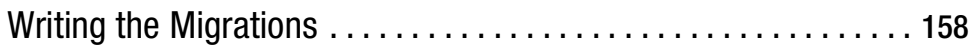

The Models' Relationships and Validations . . . . . . . . . . . 160

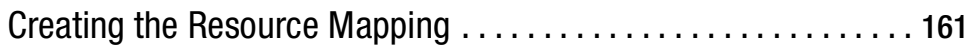

The Blog Name Helper Method ..................... 161 
Adding the Blog Title to the Edit User Profile Page .......... 162

The Controllers and Views ......................... 163

Testing the Entries Controller ....................... 171

Creating and Testing the Comments Controller ............ 173

Adding the Latest Blog Entries to User Profiles............. 177

The Blogs Controller.............................. 178

Creating an XML-RPC Blogging Interface $\ldots \ldots \ldots \ldots \ldots \ldots \ldots \ldots$

Action Web Service............................... 181

Generating the Web Service Code .................... 181

Defining the API Method Calls ........................ 182

Writing the Blogging API Method Code................. 184

Testing the Web Services .......................... 186

Testing Using a Desktop Blogging Client. . . . . . . . . . . 186

Automated Testing of the Blogging API . . . . . . . . . . . . 188

Further Development of the Blogging System ................ 189

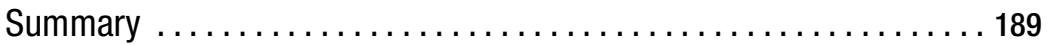

CHAPTER 7 Building a Photo Gallery $\ldots \ldots \ldots \ldots \ldots \ldots \ldots \ldots \ldots \ldots \ldots \ldots \ldots \ldots \ldots$

Working with Uploaded Files $\ldots \ldots \ldots \ldots \ldots \ldots \ldots \ldots \ldots \ldots \ldots \ldots$

The attachment_fu Plug-in ........................... 192

The Photo Gallery Requirements ........................ 194

Defining the Photo Model. .......................... 195

The Photos Controllers.......................... 195

Installing ImageMagick, RMagick,

and attachment_fu ................................ 195

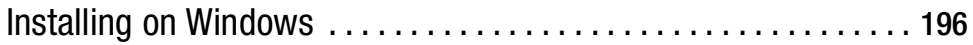

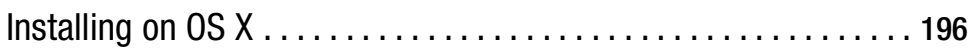

Installing on Linux............................. 196

Installing the attachment_fu Plug-in . . . . . . . . . . . . 196

Building the Photo Gallery . ......................... 197

Generating the Scaffolding Code .................... 197

Writing the Migration . . . . . . . . . . . . . . . . . . . . . 198

Creating the Photo Model and Its Relationships . . . . . . . . 199

Mapping the Photos Resource $\ldots \ldots \ldots \ldots \ldots \ldots \ldots \ldots \ldots . \ldots 200$

The Photos and User Photos Controllers ................ 200

The Photo Views .............................. 203

Manually Testing the Gallery $\ldots \ldots \ldots \ldots \ldots \ldots \ldots \ldots \ldots \ldots \ldots$ 


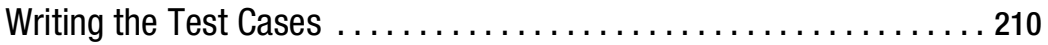

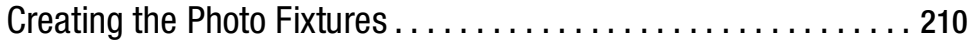

Unit Testing .................................... 210

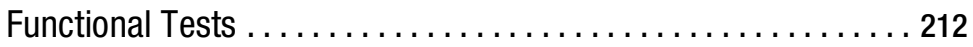

Further Development of the Photo Gallery $\ldots \ldots \ldots \ldots \ldots \ldots \ldots \ldots 215$

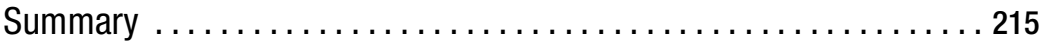

\section{CHAPTER 8 Sending E-mail and Building}

a Newsletter Mailing List $\ldots \ldots \ldots \ldots \ldots \ldots \ldots \ldots \ldots \ldots \ldots \ldots \ldots \ldots \ldots$

Using ActionMailer ................................. 217

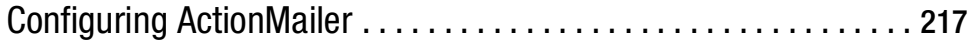

Specifying the E-mail Feature Requirements $\ldots \ldots \ldots \ldots \ldots \ldots \ldots 218$

E-mail Notifications of New Comments .................. 219

E-mail Newsletters ............................. 219

Building the New Comment Notifier . .................. 220

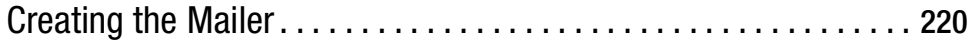

Manually Testing E-mail Creation.................... 223

Calling the Mailer from the Comments Controller........... 226

Testing the Mailer from Within the Application . . . . . . . . . . 227

Automating the Mailer Tests . . . . . . . . . . . . . . . . . . 228

Building the Newsletter Feature $\ldots \ldots \ldots \ldots \ldots \ldots \ldots \ldots \ldots . \ldots . \ldots 230$

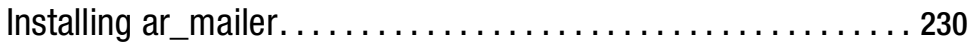

Creating the Skeleton Resource . . . . . . . . . . . . . . . . 232

Mapping the Newsletter Resource $\ldots \ldots \ldots \ldots \ldots \ldots \ldots \ldots 233$

The Newsletter Model .............................. 234

Writing the Newsletter Controller and Views.............. 234

Creating the Newsletter Mailer ...................... 241

Add the Newsletters to the Sidebar . . . . . . . . . . . . . . 241

Testing the Newsletter Mailer . . . . . . . . . . . . . . . . . 242

Further Development of the E-mail System . . . . . . . . . . . . . . 244

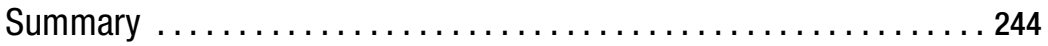

CHAPTER 9 Adding Friends with XFN Details $\ldots \ldots \ldots \ldots \ldots \ldots \ldots 247$

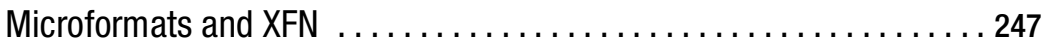

The Friends Feature Requirements . . . . . . . . . . . . . . . 249

The Friends Resource............................ 249

Showing Users' Latest Activities.................... 251 


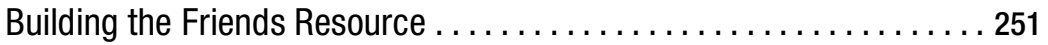

Creating the Database Migrations $\ldots \ldots \ldots \ldots \ldots \ldots \ldots \ldots 251$

Building the Friends Resource .................... 254

Updating the User's Latest Activity................... 257

The Friends Controller and Views..................... 258

Adding Friends Links to the Sidebar Menu ............... 267

Styling the Friends List ............................. 269

Testing ........................................ 272

Further Development of the Friendship Feature $\ldots \ldots \ldots \ldots \ldots \ldots .274$

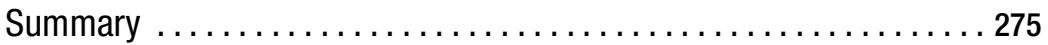

CHAPTER 10 Adding Tags to the Photo Gallery $\ldots \ldots \ldots \ldots \ldots \ldots \ldots 277$

The Gallery Tagging Requirements . . . . . . . . . . . . . . . 277

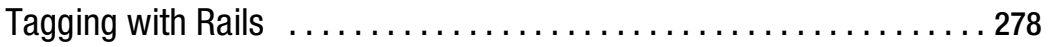

The acts_as_taggable_on_steroids Plug-in . ................ 279

Building the Photo Tagging Feature $\ldots \ldots \ldots \ldots \ldots \ldots \ldots \ldots 282$

Installing the acts_as_taggable_on_steroids Plug-in . . . . . . 282

Creating the Database Tables ...................... 283

Updating the Models. ............................. 284

Creating the Controllers ......................... 285

Adding the Resource Mappings . .................... 285

Writing the Controllers and Views.................... 286

Adding Tags to a Photo ............................ 290

Linking to the Tag Browser . . . . . . . . . . . . . . . . . 295

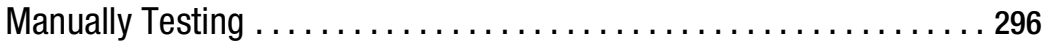

Further Development of the Tagging System $\ldots \ldots \ldots \ldots \ldots \ldots \ldots 298$

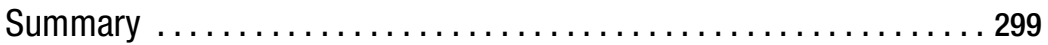

CHAPTER 11 Creating Mashups and Integrating with Web $2.0 \ldots \ldots . .301$

Integrating the Google Maps API ...................... 301

The Mapping Feature Requirements .................. 302

Building the Mapping Feature ..................... 303

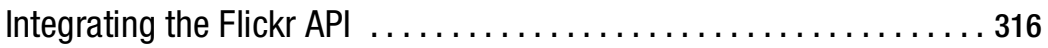

The Flickr Feature Requirements .................. 317

Building the Flickr Integration Feature ................. 317

Further Development Using Mashups $\ldots \ldots \ldots \ldots \ldots \ldots \ldots \ldots \ldots \ldots$

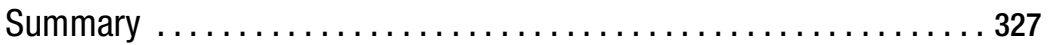




\section{CHAPTER 12 Adding User-Created Themes}

The Blog Template Requirements ...................... 329

Liquid Templates ................................. 330

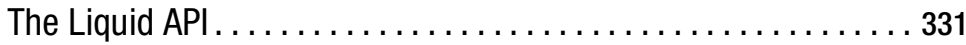

Liquid Markup................................. 331

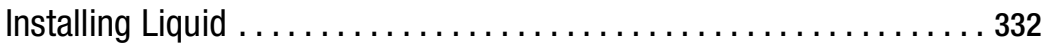

Building the Blog Templates Feature $\ldots \ldots \ldots \ldots \ldots \ldots \ldots \ldots \ldots \ldots \ldots$

Creating the Liquid Drops $\ldots \ldots \ldots \ldots \ldots \ldots \ldots \ldots \ldots \ldots \ldots \ldots \ldots$

Creating the Liquid Filters ......................... 336

The Usertemplate Model . . . . . . . . . . . . . . . . . . . . 337

The Usertemplates Controller . . . . . . . . . . . . . . . . . . 338

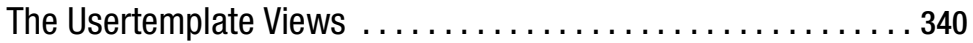

Rendering Liquid Templates . . . . . . . . . . . . . . . . . . . 342

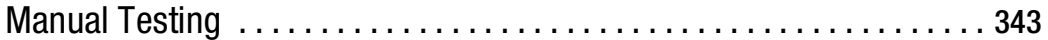

Testing the Usertemplates Controller ..................... 346

Further Development of the User Templates . . . . . . . . . . . . . 348

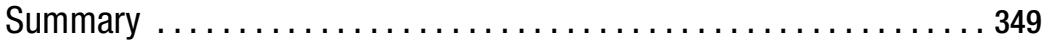

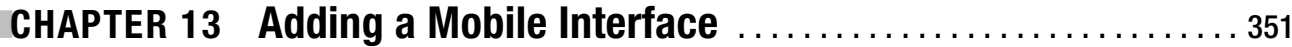

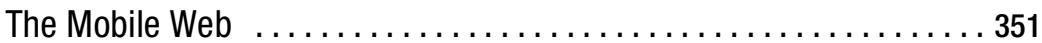

The RailsCoders Mobile Site Requirements ................. 352

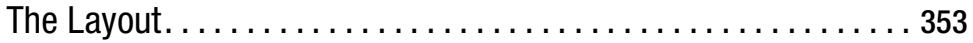

User Profiles ..................................... 354

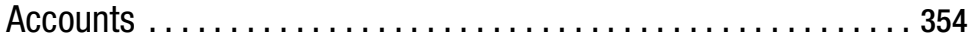

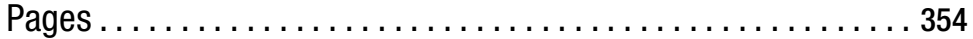

News Articles .................................. 354

Forums...................................... 354

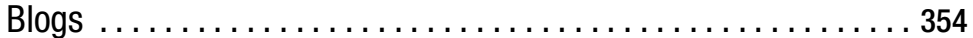

Photo Gallery ................................. 355

Developing Mobile RailsCoders .......................... 355

Structure of the Mobile Application $\ldots \ldots \ldots \ldots \ldots \ldots \ldots \ldots \ldots \ldots \ldots$

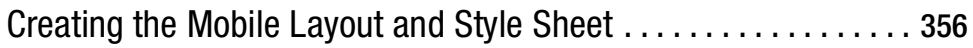

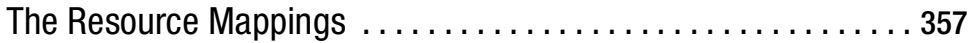

The Mobile Controllers and Views. ................... 360

Manual Testing .................................... 375

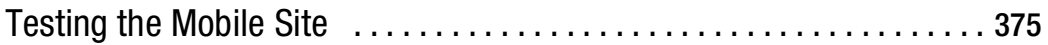

Further Development of the Mobile Site ................... 377

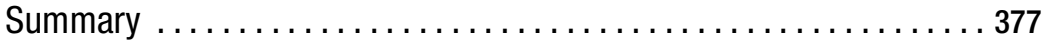


CHAPTER 14 Deploying, Optimizing, and Scaling the Application .... 379

Deploying RailsCoders $\ldots \ldots \ldots \ldots \ldots \ldots \ldots \ldots \ldots \ldots \ldots \ldots \ldots \ldots \ldots \ldots$

Development Mode vs. Production Mode ............... 379

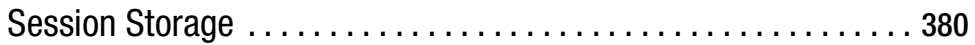

Choosing a Host ............................... 381

Choosing a Web Server ................................ 382

Automating Deployment with Capistrano and Deprec ......... 383

Optimizing and Scaling RailsCoders . . . . . . . . . . . . . . . . 392

Watching the $\log$ Files........................ 392

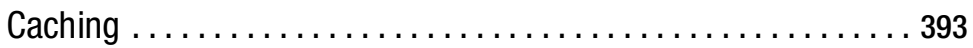

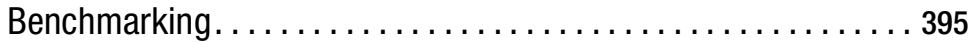

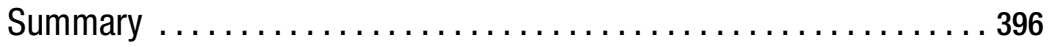

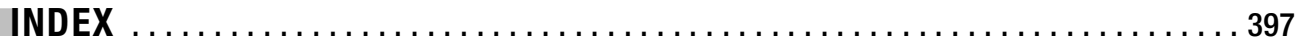




\section{About the Author}

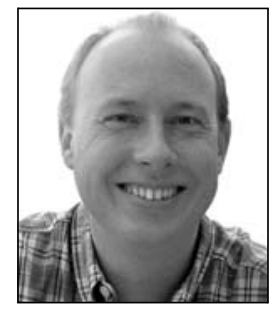

ALAN BRADBURNE is an independent Rails developer providing consulting services and developing applications for companies, both large and small. Alan has over ten years' experience in the Web and mobile industries, and has worked for Motorola, Nextel, and Sun Microsystems. In 2002, he created Phlog.net, one of the world's first dedicated mobile photo blogging communities. He then went on to work with 20six, helping to develop their blogging community software.

Since 2005, he has been working with Rails full time, developing applications for web start-ups and enterprise clients. He has spoken at a number of events on Rails development and has presented on agile development techniques and Rails coding.

He lives in Reading, England, with his wife, Mayumi. In his spare time, he enjoys learning Japanese, playing the occasional game of Go, and traveling as often as possible. You can find him online at http://alanbradburne.com. 


\section{About the Technical Reviewer}

PAUL BENTLEY has been writing software professionally for over a decade. He has experience in many areas of computing, from embedded devices to 3-D graphics. He is especially proficient in the telephony world and is experienced with both traditional computer telephony and SIPbased solutions. He is currently working with Rails, developing web applications for corporations that want stable solutions to a variety of problems.

As an avid Go player, he tries to play every day — though he admits he still has a lot to learn before he can even be considered an amateur. He lives with his girlfriend and daughter in Harrogate, UK. If you feel like challenging Paul to a game of Go, he can be tracked down via paulbentley.net. 


\section{Acknowledgments}

his book could not have been written without the help, guidance, and support of many people from Apress, the Ruby and Rails communities, friends, and family.

First of all, thanks to Peter Cooper for planting the seed of the idea to write this book and putting me in touch with Apress.

I would like to thank Keir Thomas for his encouragement and guidance during the early stages of the book. His advice and support were invaluable in my initial planning and writing.

Thanks to Kylie Johnston for being a wonderful project manager. She has been there every step of the way supporting me and keeping things moving.

Huge thanks go to Paul Bentley, Matt Moodie, and Chris Mills for doing such a fine job reviewing the book and providing constructive feedback.

I would also like to thank Heather Lang for her great work in copy editing the book and everybody else at Apress involved in the creation of this book.

Many thanks to the Rails community as a whole for making this such an exciting, interesting, and generally pleasant industry to work in. Special thanks go to Yukihiro Matsumoto and David Heinemeier Hansson for creating Ruby and Rails respectively.

Finally, I would like to thank my family and friends for their support during the writing of this book. Thanks go to my parents and Mayumi's parents for their encouragement and for putting up with my writing over Christmas and New Year. Special thanks must go to my wife, Mayumi, for her constant support and endless patience. 


\section{Introduction}

S

ocial networking sites have become increasingly popular and important for users of the Internet. Many people keep in touch with friends with sites such as Facebook and MySpace, and other sites such as LinkedIn allow people to connect and discuss topics in a business context.

Ruby on Rails has dramatically lowered the barriers to developing complex, maintainable, and scaleable web applications. This makes it a great tool to allow developers to easily build social sites that are tailored for the unique needs of a specific community.

I wrote this book to show you how to make use of Ruby on Rails and some of the available plug-ins and tools to build a unique site for your own community.

\section{Who This Book Is For}

Practical Rails Social Networking Sites is for developers who want to learn how to build a realworld web application using Ruby on Rails. This book is aimed at developers who have already worked through some Rails tutorials and have developed an application and now wish to build their skills and develop a social networking site using Rails.

\section{How This Book Is Structured}

Throughout the book, I will build a real-world social networking site called RailsCoders. In each chapter, I will address a different feature of the site, specifying the requirements of the feature and writing the code for it. You can use all of the code in the book to easily build your own social networking site or adapt the code for each feature to meet your own requirements.

This book is designed to be a practical guide to developing a site, rather than a reference book or a tutorial to Rails; I will point out useful resources for further information throughout this book.

I encourage you to get involved in the RailsCoders site itself at http://railscoders.net. You can use the forums to discuss topics from this book or create a blog to discuss your own Rails development experiences. 


\section{Downloading the Code}

You can download a zip file containing the source code from the book from both the Apress web site at http://apress.com and the RailsCoders site at http://railscoders. net.

\section{Contacting the Author}

You can reach Alan Bradburne by e-mail at abradburne@gmail. com or follow his blog at http://alanbradburne.com. 